\title{
Studies of the pathogenesis and immunology of attenuated mutants of Salmonella enterica var. Typhimurium: lessons for human typhoid fever?
}

\author{
Sarah J. Dunstan ${ }^{1}$, Cameron P. Simmons ${ }^{1,2}$, Odilia L.C. Wijburg ${ }^{1,3}$, Tania K. Uren ${ }^{1,2}$, Nico van Rooijen ${ }^{3}$,
} Richard A. Strugnell 1,2

\begin{abstract}
Abstrak
Salmonella enterica var Typhi menyebabkan penyakit sistemik pada manusia seperti halnya $S$. enterica var Typhimurium pada mencit. Pada mencit, resistensi terhadap S. Typhimurium terutama dikendalikan oleh lokus genetik yang menyandi NRAMP-1, suatu protein yang ditemukan dalam ruang fagosomal makrofag. Dua alel fenotip dari NRAMP-1, yaitu Ity dan Ity', menyebabkan mencit berbeda dalam kepekaannya terhadap S. Typhimurium sampai 10.000 kali lipat. Tidak jelas apakah terdapat alel dengan struktur yang mirip pada NRAMP-1 manusia, walaupun demikian telah dilaporkan adanya keragaman dalam transkripsi NRAMP-1 manusia. Imunologi dari tifoid murine sampai saat ini dianggap mirip dengan demam tifoid manusia. Tetapi perbedaan sifat mutan $S$. Typhimurium pada mencit dan mutan S. Typhi pada manusia yang ditemukan baru-baru ini, menunjukkan bahwa mungkin terdapat perbedaan penting dalam hubungan pejamu-patogen. Kami tertarik untuk menentukan sifat kunci dari S. Typhimurium sebagai vektor vaksin, sedemikian rupa sehingga sifat-sifat yang mirip dapat direkayasa pada $S$. Typhi yang dilemahkan. Kami telah mempelajari ekspresi fragmen $C$, bagian dari toksin tetanus yang protektif dan non-toksik, dan meneliti kapasitas dari berbagai mutasi S. Typhimurium, replikon dan promoter untuk menghasilkan respon protektif. Berbagai mutan dianalisa tentang penetrasinya ke organ sentral, seperti hati dan limpa, setelah pemberian oral, serta kemampuannya untuk menginduksi respons sel B dan sel T yang spesifik Salmonella dan toksoid tetanus. Terdapat hubungan yang baik antara masuknya dan bertahannya di dalam plak Peyeri dengan kadar antibodi, tetapi tidak ada korelasi antara respon antibodi dengan invasi limpa. Terdapat hubungan positif antara respon sel T limpa dengan invasi limpa. Sebagai bagian dari program penelitian yang lebih luas untuk menentukan sel yang berperan pada induksi dan berpengaruh pada kekebalan tifoid murine, penelitian tentang peran makrofag dan induksi melawan paparan Salmonella juga telah dilakukan pada mencit. Makrofag mencit dihilangkan dengan teknik deplesi $\mathrm{Cl}_{2} \mathrm{MDP}$-macrophage sebelum imunisasi dan/atau sebelum paparan. Mencit yang dihilangkan makrofagnya sebelum dan selama imunisasi dengan S. Typhimurium $\triangle$ AroA/aroD (je. BRD509) yang mengekspresi fragmen C ternyata sangat terproteksi terhadap paparan S. Typhimurium SL 1344; proteksi ini berkurang bila makrofag dihilangkan sebelum paparan. Penghilangan makrofag tidak mengurangi respon antibodi terhadap toksoid tetanus, tetapi sebaliknya, penghilangan makrofag meningkatkan respon sel $T$ yang spesifik untuk fragmen C. Hasil- hasil tersebut di atas menunjukkan bahwa makrofag bukanlah sel penyaji antigen (antigen presenting cell) yang utama berperan pada kekebalan yang ditimbulkan oleh paparan BRD509. Walaupun demikian, makrofag merupakan efektor yang penting pada proteksi terhadap infeksi S. Typhimurium virulen. Hasil penelitian ini menunjukkan bahwa masuknya Salmonella ke dalam makrofag tidak penting untuk respon homolog dan heterolog yang disebabkan oleh mutan-mutan S. Typhimurium dan bahwa banyak dari proses induktif yang berhubungan dengan kekebalan terhadap Salmonellae virulen, mungkin terjadi di plak Peyeri. Jelaslah bahwa hubungan antara Salmonellae dan sel pejamu di dalam plak Peyeri perlu dikaji lebih lanjut pada model murine, serta perlu diusahakan untuk menentukan hubungan S. Typhi-makrofag pada manusia.
\end{abstract}

\begin{abstract}
Salmonella enterica var. Typhi and Typhimurium cause similar systemic disease in humans and mice respectively. In mice, resistance to $S$. Typhimurium is largely controlled by a genetic locus which encodes NRAMP-I (a protein found within the phagosomal compartment of macrophages. The two phenotypic alleles of NRAMP-1). Ity ${ }^{\mathrm{S}}$ and It $\mathrm{R}^{\mathrm{R}}$, cause mice to vary in sentivity to S. Typhimurium by 10,000-fold. It is not clear whether there are similar structural alleles in human NRAMP-1, but variability in human NRAMP-1 transcription has been reported. The immunology of murine typhoid was, until recently, thought to closely parallel that of human typhoid fever but recent discrepancies in the behaviour of defined S. Typhimurium and S. Typhi mutants in mice and humans respectively, suggest that there may be some important differences in the host-pathogen relationships. Our interests have been in defining the key properties of S. Typhimurium as a vaccine vector such that similar properties could be engineered into attenuated $S$. Typhi. We have studied the expression of $C$ fragment, the protective but non-toxic portion of tetanus toxin, and examined the capacity of different $S$. Typhimurium mutations, replicons and promoters to deliver protective responses. Mutants were analysed for penetration into central organs eg. liver and spleen, after oral
\end{abstract}

1 Department of Microbiology and Immunology

2 CRC for Vaccine Technology, University of Melbourne,

Parkville, Victoria, Australia 3052

3 Department of Cell Biology and Immunology,

Vrije University, Amsterdam, The Netherlands 
administration, and for their capacity to elicit Salmonellae- and tetanus toxoid-specific $T$ and $B$ cell responses. There was a good correlation between entry into, and persistence within, the Peyer's patches and antibody levels, but no correlation between antibody responses and splenic invasion. There was a positive correlation between splenic T cell responses and splenic invasion. Studies into the role of macrophages and the induction of protection against Salmonellae challenge were also conducted in mice, as part of a larger program to define the cells responsible for inducing and effecting immunity in murine typhoid. Mice were depleted of macrophages prior to immunisation and/or prior to challenge using the $C l_{2} M D P$-macrophage depletion techique. Mice depleted of macrophages prior to and during immunisation with S. Typhimurium aroA/aroD (ie. BRD509) expressing C fragment were highly protected against challenge with S. Typhimurim SL 1344; this protection was reduced when macrophages were removed prior to challenge. Macrophage depletion did not reduce antibody responses against tetanus toxoid but, paradoxically, macrophage depletion increased $T$ cell responses specific for $C$ fragment. This results suggest that macrophages are not the primary antigen presenting cell (APC) involved in immunity elicited by BRD509. However, macrophages appear to be important effectors in protection againts virulent S Typhimurium challenge infection. The results from these studies indicate that Salmonella entry into macrophages is not essential for homologous or heterologous responses elicited by mutants of $S$. Typhimurium and that much of the inductive processes with respect to immunity against virulent Salmonellae, and the heterologous antigens they are engineered to express, may occur in the Peyer's patch. Clearly, the relation between Salmonellae and host cells within the Peyer's patch should be explored further in the murine model and attempts should be made to define the $S$. Typhi-macrophage relationship in humans.

\section{INTRODUCTION}

Infections by Salmonella enterica, especially typhoid fever, remain significant causes of human morbidity and mortality at the close of the 20th Century 18 . In the face of successful vaccination campaigns and improved control of many infectious diseases, why does typhoid fever remain an important human illness? Part of the answer must lie in the current vaccines, which have variable efficacy, our relatively poor understanding of the pathogenesis of typhoid, and the absence of well tested immune correlates of protection, which might be used to define new and improved typhoid fever vaccines.

Studies of S. enterica var. Typhi are handicapped by the very narrow host range of this bacterium, especially compared with many other $S$. enterica ${ }^{18}$. S.Typhi has evolved an obligate and close relationship with humans and can locate to ecological niches, eg. the gall bladder, that are both unusual and important to the establishment and maintenance of the carrier state, the least likely outcome for a host-pathogen relationship. The limited host range for $S$.Typhi has meant that most studies in the modern era of immunology, molecular and cell biology have relied on a murine model of human typhoid which uses the mouse pathogen $S$. enterica var. Typhimurium. The predictive value of the murine typhoid model, once thought to be very good, has been somewhat eroded by vaccine studies which showed that different attenuated mutants of S. Typhimurium and their S. Typhi homologues (eg. galE mutants9,10) behaved differently in mice and humans respectively. In many other studies however, the phenotype of S. Typhimurium mutants in mice has closely paralleled the behaviour of counterpart S. Typhi mutants in humans $1,8,11,14,19,24,25$.

Our studies of murine typhoid have focused on two questions - (a) how and where are cells which may mediate immunity engaged and what are the relevant antigen presenting cells (APCs) for the T cells in these responses and, conversely, (b) what properties of an S.Typhimurium vaccine strain are essential to elicit protective levels of immunity against co-expressed ie. heterologous antigens and S. Typhimurium. It has long been held that Salmonellae are intramacrophage pathogens ${ }^{17}$. This tenet was developed largely by analogy with other bacterial pathogens, such as Mycobacterium tuberculosis, which are similarly poorly controlled by antibody responses alone, and which requires T cells of the TH1 subtype ie. which produce gamma interferon (IFN-g) for immune protection ${ }^{15}$. The current theory on resistance to Salmonella reinfection requires that immune $\mathrm{T}$ cells recognise S.enterica-infected cells as de facto APCs, or professional APCs presenting S. enterica determinants, produce IFN- $\gamma$ which, in turn, activates macrophages harbouring bacteria, leading to death of the bacteria. We were interested in determining the role of macrophages in both the induction of protective immune responses ie. as APCs, and their role as effectors of immunity.

The advent of molecular biology has facilitated the construction of defined mutants of many bacteria, including $S$. enterica. The pioneering work by Hoiseth and Stocker ${ }^{8}$ showed that mutants of S.Typhimurium, which carried deletions or insertions in genes encoding enzymes of the aromatic biosynthetic pathway, 
were both attenuated and protective as vaccines. These studies led to the construction of aromatic mutants in many unrelated pathogens 22 helped refine the concept of 'rational attenuation' using site-specific mutation. Subsequent investigations have shown that pathogenic $S$. enterica can be attenuated by deletion, or insertional inactivation, of genes encoding regulatory proteins (eg. PhoP, OmpR, Cya, Crp), stress response proteins (HtrA), enzymes from other biosynthetic pathways (PurA, PurE, GalE), and putative macrophage resistance proteins $(\mathrm{PagC}) 1,3,4,6,7,9,16$. In many cases, mutants are not only attenuated but also elicit protective immune responses, and the use of multiple mutations which effect different metabolic or regulatory pathways has also been examined (aro/htrA $)^{1}$. We wished to compare the in vivo behaviour of defined $S$.Typhimurium mutants which elicited protective immune responses with mutants that were incapable of inducing homologous protection, in an attempt to define properties fundamental to successful vaccine strains, and to determine the relative capacities of the different mutants to deliver a heterologous antigen.

\section{MATERIALS AND METHODS}

S. enterica var Typhimurium strains were generously provided by Prof. G. Dougan, Imperial College, London (SL1344, $\triangle a$ roA, $\triangle$ aroAlaroD, $\triangle$ ompR, $\triangle p u r A$, $\triangle h t r A$,), and Prof. Roy Curtiss III, Washington University, St. Louis (SR-11 $\Delta c y a / c r p$ ). The C fragment expression plasmid pTETtac4 has been described previously 5 . Bacteria were cultured in LB broth and enumerated on LB agar plates. Organ counts of viable bacteria were performed on tissues disrupted in a Seward Stomacher Lab Blender 80.

Antibody levels were determined by ELISA using tetanus toxoid (CSL Ltd, Parkville, VIC, Australia) coated plates at $2 \mathrm{Lf} / \mathrm{ml}$, or S. typhimurium LPS (Sigma, St. Louis, MO, USA) coated plates at $10 \mathrm{ug} / \mathrm{ml}$. Kinetic ELISA 12,26 rates were determined using Delta SOFT II software (BioMetallics Inc, Princeton, NJ, USA), with sera diluted $1 / 100$ and 1/1000. Splenic $T$ cells were enriched on nylonwool 11 , cultured in 96-well trays with added irradiated syngeneic APCs, and proliferated with recombinant $\mathrm{C}$ fragment-(His) $)_{6}$ purified on nickel affinity matrix, added at $1.25 \mu \mathrm{g} / \mathrm{ml}$ or $10 \mu \mathrm{g} / \mathrm{ml}$, or with concanavalin A (Sigma, St. Louis, MO, USA) at $5 \mu \mathrm{g} / \mathrm{ml}$.

Macrophages were depleted from mice using intravenous (i.v.) administration of liposome-encapsulated $\mathrm{Cl}_{2} \mathrm{MDP}$ (dichloromethylene diphosphonate) ${ }^{27}$ given 2 days prior to i.v. immunisation with SL1344 $\triangle$ aroA/aroD (BRD509), then weekly thereafter for 6 weeks, and/or 2 days prior to i.v. challenge with SL1344, and at weekly intervals 1-2 weeks thereafter.

\section{RESULTS}

\section{Antibody Responses to Different Mutants of S.Ty- phimurium}

Groups of five mice were orally immunised with approximately $10^{10}$ bacteria (one of 5 mutants expressing $\mathrm{C}$ fragment) on days 0 and day 28 and bled at fortnightly or weekly intervals. Individual sera were reacted in kinetic ELISAs to detect $S$. Typhimurium lipopolysaccharide (LPS)- and tetanus toxoid (TT)specific antibodies. The values are the mean kinetic ELISA rate ( $\mathrm{mOD} / \mathrm{min}$ ) for each of the groups at day 14 , day 28 , day 42 and day 56 . The ratios of the two values is also provided. The aro mutants elicited high serum antibody levels against both $S$. Typhimurium LPS and TT. The cyalcrp mutant expressing $\mathrm{C}$ fragment elicited high level responses against TT, but a low level response against LPS. The purA mutant of

Table 1. Ratio of Anti-S.typhimurium: Anti-Tetanus Antibody Responses in infected Mice

\begin{tabular}{|c|c|c|c|c|c|c|c|c|c|c|c|c|}
\hline \multirow{2}{*}{ Mutant } & \multicolumn{3}{|c|}{ Day 14} & \multicolumn{3}{|c|}{ Day 28} & \multicolumn{3}{|c|}{ Day 42} & \multicolumn{3}{|c|}{ Day 56} \\
\hline & LPS $^{a}$ & $\mathrm{TT}^{\mathrm{b}}$ & $\mathrm{R}^{\mathrm{c}}$ & LPS & TT & $\mathrm{R}$ & LPS & $\mathrm{TT}$ & $\mathrm{R}$ & LPS & TT & $\mathrm{R}$ \\
\hline aroA & 21 & 144 & 0.15 & 107 & 265 & 0.39 & 186 & 371 & 0.50 & 161 & 336 & 0.48 \\
\hline aroA/aroD & 22 & 214 & 0.10 & 994 & 353 & 0.27 & 145 & 417 & 0.35 & 125 & 339 & 0.37 \\
\hline purA & 16 & 27 & 0.59 & 39 & 59 & 0.66 & 87 & 110 & 0.87 & 122 & 131 & 0.93 \\
\hline htrA & 37 & 223 & 0.16 & 107 & 350 & 0.30 & 233 & 423 & 0.55 & 199 & 371 & 0.53 \\
\hline cyalcrp & 14 & 225 & 0.06 & 39 & 443 & 0.09 & 82 & 404 & 0.20 & 772 & 399 & 0.18 \\
\hline
\end{tabular}

a. ELISA kinetic rate value of serum Ig for S.Typhimurium LPS (mean, 5 mice)

b. ELISA kinetic rate value of serum Ig for tetanus toxoid (TT) (mean, 5 mice)

c. ratio of rate values S.Typhimurium LPS/tetanus toxoid 
Table 2. Spleen to Peyer's Patch Count Ratios in S.Typhimurium-infected mice

\begin{tabular}{|c|c|c|c|c|c|c|c|c|c|}
\hline \multirow{2}{*}{ Mutant } & \multicolumn{3}{|c|}{ Day 7} & \multicolumn{3}{|c|}{ Day 14} & \multicolumn{3}{|c|}{ Day 21} \\
\hline & $\mathrm{PP}^{\mathrm{d}}$ & $S p 1^{e}$ & $R^{f}$ & PP & Spl & $\mathrm{R}$ & PP & Sp1 & $\mathrm{R}$ \\
\hline $\operatorname{aro} A$ & 4.6 & 2.9 & 1.6 & 4.1 & 3.1 & 1.3 & 3.1 & 2.5 & 1.2 \\
\hline aroA/aroD & 5.8 & 3.0 & 1.9 & 4.4 & 3.2 & 1.3 & 3.6 & 2.0 & 1.8 \\
\hline purA & 2.8 & 2.6 & 1.2 & 2.0 & 3.1 & 0.6 & $<0.7$ & 2.6 & $<0.3$ \\
\hline$h t r A$ & 4.6 & 2.4 & 1.9 & 3.2 & 1.6 & 2.0 & 2.2 & $<0.7$ & $>3.1$ \\
\hline cyalcrp & 5.8 & 3.2 & 1.8 & 4.2 & 2.6 & 1.6 & 3.2 & 3.3 & 0.9 \\
\hline
\end{tabular}

d. mean number ( $\left.\log _{10}\right)$ of bacteria isolated from Peyer's patches of 3-4 mice

e. mean number $\left(\log _{10}\right)$ of bacteria isolated from spleens of 3-4 mice

$f$ ratio of Peyer's patch counts to spleen counts

$S$. Typhimurium induced low levels of C fragment antibodies, which were shown in a separate study to be non-protective (data not presented).

\section{Ratio of Spleen Counts to Peyer's Patch Counts}

The number $\left(\log _{10}\right)$ of bacteria present in the Peyer's patches (PP) and spleens $(\mathrm{Spl})$ of mice orally infected with the different mutants is shown in Table 2. The highest counts in PP and Spl were observed in mice infected with the aro mutants and with the cyalcrp mutant. The purA mutant colonised Peyer's patches at a low level. In contrast, $h$ trA mutants invaded into the spleen at relatively low levels. The ratios of the counts were similar for all mutants at Day 7 , suggesting that entry into the spleen early after infection correlated with the number of bacteria which had penetrated into the Peyer's patches. After this time point however, the ability of the mutants to sustain colonisation at the two sites varied. This suggests that the immune responses elicited by the different mutants may be different and affect the clearance or persistence of the bacteria.

\section{Correlation between Splenic Counts and Spleen $T$ cell Proliferation/Cytokine Expression}

The ability of the different $S$.Typhimurium mutants expressing $\mathrm{C}$ fragment to elicit splenic $\mathrm{T}$ cell responses was also examined and correlated with invasion into spleen. Splenocytes, and splenocytes enriched for T cells, were removed from orally immunised mice and examined for specific proliferation (enriched $\mathrm{T}$ cells from spleens removed 28 days post infection) and IFN- $\gamma$ production (splenocyte bulk cultures removed 21 days post infection) after incubation with $\mathrm{C}$ fragment. Splenocytes from naive mice and mice immunised with $S$. Typhimurium alone did not proliferate or produce IFN- $\gamma$ when incubated with
$\mathrm{C}$ fragment. The best proliferative responses, and the highest levels of IFN- $\gamma$ production were observed when mice were challenged with $\mathrm{C}$ fragment expressed from the aroA/aroD mutant.

Table 3. Bacterial Counts in the Spleen, Splenic T Lymphocyte Proliferation and Cytokine Production by Splenocytes from Immunised Mice

\begin{tabular}{cccc}
\hline Mutant & $\begin{array}{c}\text { Spleen } \\
\text { counts }^{\mathrm{g}}\end{array}$ & $\begin{array}{c}\text { T cell Prolif } \\
(\mathrm{SI})^{\mathrm{h}}\end{array}$ & $\begin{array}{c}\text { IFN- } \gamma \\
(\mathrm{ng} / \mathrm{m}])^{\mathrm{i}}\end{array}$ \\
\hline aroA/aroD & 3.2 & 21 & 5.27 \\
purA & 3.1 & 5 & 1.04 \\
htrA & 1.6 & 13 & 1.00 \\
cya/crp & 2.6 & 17 & 1.18 \\
naive & - & 1 & 0.03 \\
aroAlaroD-C & $\mathrm{ND}$ & 2 & 0.03 \\
\hline
\end{tabular}

g. number of bacteria in the spleen at day 14 , (ie. peak spleen count)

h. stimulation index; $\mathrm{cpm}$ incorporated by enriched $T$ cells stimulated with $1.25 \mu \mathrm{g} / \mathrm{ml}$ of C fragment cpm incorporated by enriched T cells incubated in medium alone

i. spleen cell cultures were incubated with $10 \mu \mathrm{g} / \mathrm{ml}$ $C$ fragment and the amount of IFN- $\gamma$ produced was quantitated in an IFN-g ELISA

ND not done

\section{Effect of Macrophage Depletion on Immunity in- duced by BRD509}

Macrophages were depleted from mice prior to i.v. immunisation with the aroA/aroD mutant of S. Typhimurium BRD509, and or prior to i.v. challenge with 100 virulent S. Typhimurium SL1344. Mice were killed 4 days after challenge and the number of bacteria present in the spleens and livers determined by viable count. Mice depleted of macrophages at the time of immunisation were largely protected against 


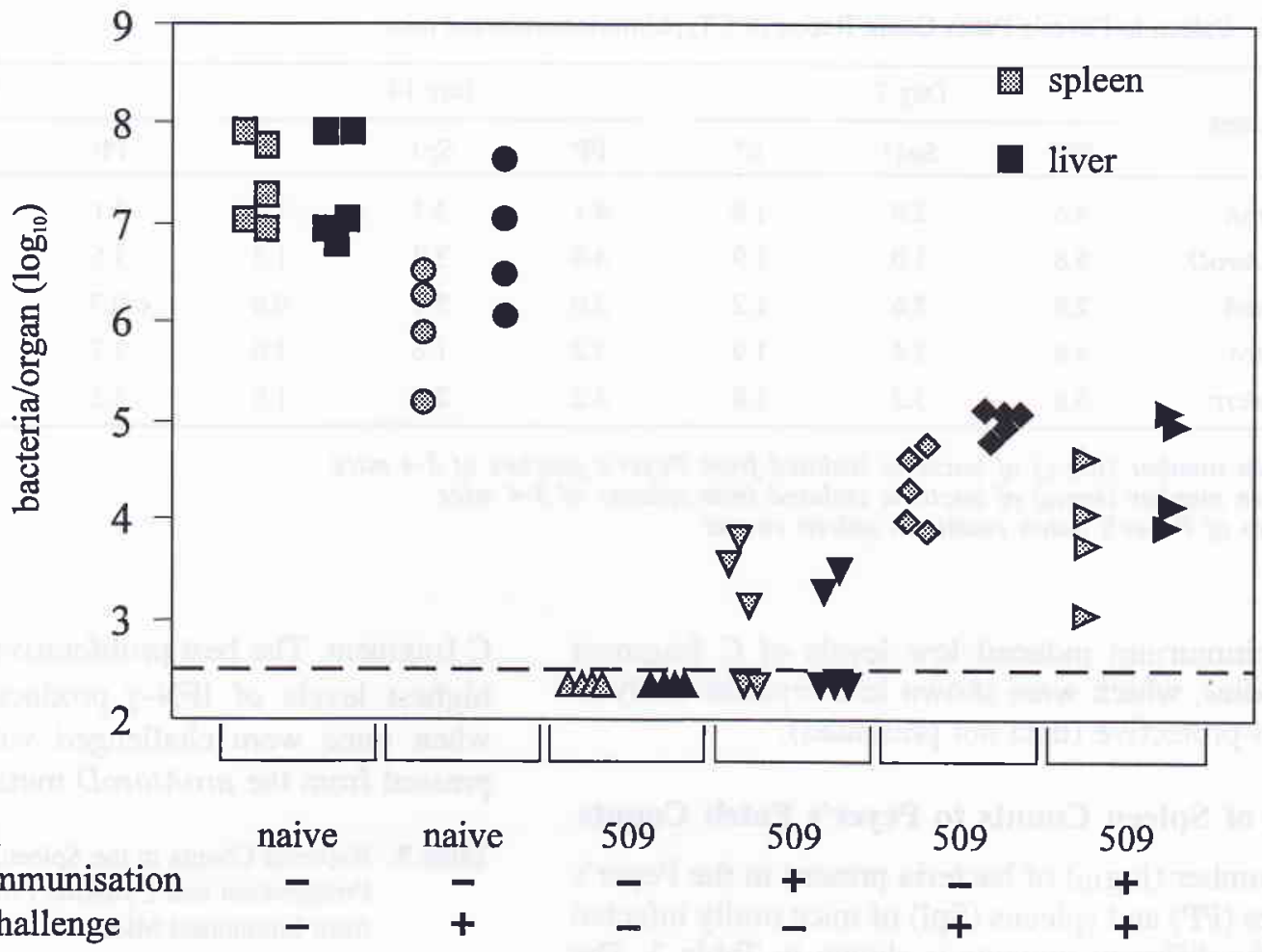

Figure 1. Effect of macrophage depletion on immunisation with BRD509 and resistance to challenge with SL1344

Mice were depleted of macrophages 2 days before immunisation with BRD509 and at weekly intervals thereafter for 6 weeks, and/or 2 days prior to challenge. Mice were challenged with 100 SL1344 and killed 4 days later. The number of bacteria in the liver and spleen of each animal was determined by viable count. The effect of macrophage depletion on challenge of naive mice was also determined.

challenge whereas mice depleted of macrophages at the time of challenge were more sensitive that nondepleted animals, but more resistant that non-immunised controls.

\section{DISCUSSION}

Human S. Typhi disease is characterised by systemic infection and inflammation of primary and secondary lymphoid tissues. Early vaccine trials with defined aromatic mutants of $S$.Typhi suggested that the strains, though severely attenuated, retained the capacity to cause a 'vaccinemia' or mild typhoid-like illness following oral administration, in about $10 \%$ of recipients 23,24 . Reactogenicity was not observed in volunteers who received $S$. Typhi carrying mutations in aroA and purA suggesting that the purA mutation further attenuated aromatic mutants of S.Typhil3. Previous studies of purine mutants in the murine typhoid model had suggested that these strains were over-attenuated, though the in vivo persistence pattern of the purA mutant was not significantly different from the aroA mutant ${ }^{19}$. Our study re-examined the in vivo growth patterns of isogenic aroA and purA mutants and compared their organ-specific persistence with other $S$. Typhimurium mutants which are known to elicit protective immune responses, with a view to determining the requirement for systemic infection in protection.

Our observations suggest that colonisation of the Peyer's patches by vaccine strains is more important for successful delivery of heterologous antigens than penetration to the spleen. S. Typhimurium with mutations in $\operatorname{aro} A / D, o m p R$, or htrA successfully colonised Peyer's patches and elicited potent responses against $\mathrm{C}$ fragment, expressed by the mutant Salmonellae. In contrast, $S$. Typhimurium $\triangle p u r A$ mutants successfully colonised the spleen but persisted poorly in Peyer's patches, and elicited very low titres (ie. non-protective levels, data not shown) of antibodies specific for $\mathrm{C}$ fragment. These results argue against a requirement for 'vaccinemia' following oral administration of human typhoid vaccines in heterologous protection, but the issue of the splenic invasion and $T$ cell responses remains unresolved. 
Immunity against reinfection by Salmonellae is thought to be largely mediated by antigen-specific $\mathrm{T}$ cell responses ${ }^{15}$. Mice immunised orally with different attenuated mutants of $S$. Typhimurium, including the $\triangle p u r A$ mutant, displayed specific (C fragment and Salmonella antigen) proliferative $\mathrm{T}$ cell responses from pools of enriched splenic $\mathrm{T}$ cells. Furthermore, bulk cultures of splenocytes from immunised animals produced IFN- $\gamma$ in response to stimulation with $\mathrm{C}$ fragment or Salmonella antigen (data not shown). Studies to-date suggest that the $S$. Typhimurium $\triangle$ purA mutant, which invades the spleen after oral immunisation, is incapable of eliciting a protective anti-S. Typhimurium response suggesting, as observed with humoral responses, that the spleen may not be the major inductive site for $\mathrm{T}$ cell responses. It will be important to study $\mathrm{T}$ cell responses in the Peyer's patch following oral infection, for their capacity to proliferate following Salmonella antigen stimulation, produce cytokines and transfer protection. Such studies are in progress.

The effect of in vivo macrophage depletion on the induction of immune responses by BRD509, the aroA/aroD mutant of $S$. Typhimurium, and the capacity of BRD509 to effect protective responses, was also examined. Depletion of macrophages at the time of immunisation, ie. during the first 6 weeks following i.v. infection with BRD509, neither greatly affected the level of protection elicited by the vaccine nor level of antibodies specific for $S$. Typhimurium LPS or C fragment. Paradoxically, T cell proliferation to $\mathrm{C}$ fragment was increased following macrophage depletion (data not shown). In contrast, removal of macrophages from mice at the time of challenge made them more significantly more susceptible to challenge with virulent $S$. Typhimurium, SL1344. Mice were not fully sensitive to infection however, suggesting that another immune mediator, perhaps antibody, played an important role in protection. These results suggest that firstly, macrophages are not the primary cells responsible for the induction of the immune responses achieved by immunisation with attenuated $S$. Typhimurium and secondly, that macrophage-mediated killing is not the sole mechanism of protection in the murine typhoid model. The former of these conclusions is supported by many recent studies which show that dendritic cells are the only cells capable of activating naive $\mathrm{T}$ cells; the increase in $\mathrm{T}$ cell responses following macrophage depletion might reflect enhanced access by dendritic cells to bacteria in depleted mice. The fact that the killed whole cell typhoid vaccine, which elicits weak if measurable $\mathrm{T}$ cell responses, is partially protective supports a role for antibodies in protection.

Most studies of murine typhoid use inbred mice. Inbred strains of mice are either very sensitive, or 1000 -fold less so, to infection by virulent $S$. Typhimurium (eg. SL1344, C5) because of allelic variation in a single gene known as NRAMP-1. The two murine phenotypes Itys and ItyR (sensitive or resistant to $S$. Typhimurium infection respectively) are represented in common inbred strains such as $\mathrm{BALB} / \mathrm{c}$ and $\mathrm{CBA}{ }^{20,21}$. The Ity phenotype has a fundamental effect on the response, both innate and acquired, to $S$. Typhimurium infection, and immunity against reinfection in the different Ity backgrounds may well be mediated by different effector populations. It is important therefore to determine which of these phenotypes most closely allies that of humans with respect to $S$. Typhi infection, only then can true correlates of protection be defined for use in analyses of vaccine-mediated protection in the appropriate Itys or ItyR murine model.

Studies of the immunology of Salmonellae infections in inbred mice would be greatly enhanced by the definition of $\mathrm{T}$ cell determinants specific for frequently represented (eg. H-2b) murine MHC Class I and Class II alleles. This would obviate the requirement for surrogate $\mathrm{T}$ cell targets such as $\mathrm{C}$ fragment or ovalbumin and recombinant Salmonellae, and would assist in defining correlates of protection against Salmonella infection. Thus far, only one Salmonella determinant has been defined, from the FliC protein in $\mathrm{C} 3 \mathrm{H}$ (ie. Ity $\mathrm{R}$ ) mice ${ }^{2}$. This determinant was shown to be immunodominant in the recall response of $\mathrm{C} 3 \mathrm{H}$ ie. ItyR mice; significantly, subsequent studies suggest that $\mathrm{T}$ cell clones specific for the FliC determinant are not protective. It is interesting to speculate as to why an antigen, which is poorly expressed on the bacterium following invasion, is a major target of the cellular immune response. Does immunodominance by a specificity from an antigen poorly expressed post-invasion by $S$. Typhimurium represent a novel means of subverting the immune response, or does the dominance of the non-protective FliC-specific $T$ cell response in Ity $R$ background reflect the fact that these animals are naturally resistant to $S$. Typhimurium infections?

\section{REFERENCES}

1. Chatfield SN, Strahan K, Pickard D, Charles IG, Hormaeche CE, Dougan G. Evaluation of Salmonella typhimurium strains harbouring defined mutations in htrA and aroA in the 
murine salmonellosis model. Microb Pathog 1992; 12: 14551.

2. Cookson BT, Bevan MJ. Identification of a natural T cell epitope presented by Salmonella-infected macrophages and recognized by $\mathrm{T}$ cells from orally immunized mice. J Immunol 1997; 158: 4310-9.

3. Curtiss RD, Kelly SM. Salmonella typhimurium deletion mutants lacking adenylate cyclase and cyclic AMP receptor protein are avirulent and immunogenic. Infect Immun 1987; 55: 3035-43.

4. Dorman CJ, Chatfield S, Higgins CF, Hayward C, Dougan G. Characterization of porin and ompR mutants of a virulent strain of Salmonella typhimurium: ompR mutants are attenuated in vivo. Infect Immun 1989; 57: 2136-40.

5. Fairweather NF, Chatfield SN, Makoff AJ, Strugnell RA, Bester J, Maskell DJ, Dougan G. Oral vaccination of mice against tetanus by use of a live attenuated Salmonella carrier. Infect Immun 1990; 58: 1323-6.

6. Galan JE, Curtiss RD. Virulence and vaccine potential of phoP mutants of Salmonella typhimurium. Microb Pathog 1989; 6: 433-43.

7. Hohmann EL, Oletta CA, Loomis WP, Miller SI. Macrophage-inducible expression of a model antigen in Salmonella typhimurium enhances immunogenicity. Proc Natl Acad Sci USA 1995; 92: 2904-8.

8. Hoiseth SK, Stocker BA. Aromatic-dependent Salmonella typhimurium are non-virulent and effective as live vaccines. Nature 1981; 291: 238-9.

9. Hone D, Morona R, Attridge S, Hackett J. Construction of defined galE mutants of Salmonella for use as vaccines. The Journal of Infectious Diseases 1987; 156: 167-74

10. Hone DM, Attridge SR, Forrest B, Morona R, Daniels D, LaBrooy JT, Bartholomeusz RC, Shearman DJ, Hackett J. A galE via (Vi antigen-negative) mutant of Salmonella typhi Ty2 retains virulence in humans. Infect Immun 1988; 56: 1326-33.

11. Julius MH, Simpson E, Herzenberg LA. A rapid method for the isolation of functional thymus-derived murine lymphocytes. Eur J Immunol 1973; 3: 645-9.

12. Kung VT, Humphries GMK. Kinetic ELISA in microtitre plates. Clin Chem 1987; 33: 1573-4.

13. Levine MM, Ferreccio C, Black RE, Tacket CO, Germanier R. Progress in vaccines against typhoid fever, Rev Infect Dis 1989; S552-67.

14. Levine MM, Herrington D, Murphy JR, Morris JG, Losonsky G, Tall B, Lindberg AA, Svenson S, Baqar S, Edwards MF, et al. Safety, infectivity, immunogenicity, and in vivo stability of two attenuated auxotrophic mutant strains of Salmonella typhi, 541Ty and 543Ty, as live oral vaccines in humans. J Clin Invest 1987; 79: 888-902.
15. Mastroeni P, Villarreal RB, Hormaeche CE. Role of T cells, TNF alpha and IFN gamma in recall of immunity to ora challenge with virulent salmonellae in mice vaccinated with live attenuated aro- Salmonella vaccines. Microb Pathog 1992; 13: 477-91.

16. McFarland WC, Stocker BAD. Effect of different purine auxotrophic mutations on mouse-virulence of a Vi-positive strain of Salmonella dublin and two strains of Salinonella typhimurium. Microbial Pathogenesis 1987; 3: 129-41.

17. Miller SI. PhoP/PhoQ: macrophage-specific modulators of Salmonella virulencé. Mol Microbiol 1991; 5: 2073-8.

18. Miller SI, Hohmann EL, Pegues DA. Salmonella (including Salmonella typhi). In Mandell GL, Bennett JE, Dolin R Eds. Principles and Practises of Infectious Diseases 1995; 2013 33. New York, USA: Churchill Livingstone.

19. O'Callaghan Ds, Maskell D, Liew FY, Easmon CS, Dougan G. Characterization of aromatic- and purine-dependent Salmonella typhimurium: attention, persistence, and ability to induce protective immunity in BALB/c mice. Infect Immun, 1988; 56: 419-23.

20. Plant J, Glynn AA. Natural resistance to Salmonella infection, delayed hypersensitivity and Ir genes in different strains of mice. Nature $1974 ; 248: 345-7$.

21. Robson G, Vas SI. Resistance of inbred mice to Salmonella typhimurium. J Infect Dis 1972; 126: 378-86.

22. Simmons CP, Hodgson ALM, Strugnell RA. Attenuation and vaccine potential of aroQ mutants of Corynebacterium pseudotuberculosis. Infect Immun 1997; 65: 3048-56.

23. Tacket CO, Hone DM, Curtiss Rd, Kelly SM, Losonsky G, Guers L, Harris AM, Edelman R, Levine MM. Comparison of the safety and immunogenicity of delta aroC delta aroD and delta cya delta crp Salmonella typhi strains in adult volunteers. Infect Immun 1992a; 60: 536-41.

24. Tacket CO, Hone DM, Losonsky GA, Guers, L., Edelman R, Levine MM. Clinical acceptability and immunogenicity of CVD 908 Salmonella typhi vaccine strain. Vaccine 1992b; 10: 443-6.

25. Tacket CO, Sztein MB, Losonsky GA, Wasserman SS, Nataro J P, Edelman R, Pickard D, Dougan G, Chatfield SN, Levine MM. Safety of live oral Salmonella typhi vaccine strains with deletions in htrA and aroC aroD and immune response in humans. Infect Immun 1997; 65: 452-6.

26. Tsang VC, Wilson BC, Peralta JM. Quantitative, single-tube, kinetic-dependent enzyme-linked immunosorbent assay (kELISA). Methods Enzymol 1983; 92: 391-403.

27. van Rooijen N, Bakker J, Sanders A. Transient suppression of macrophage functions by liposome-encapsulated drugs. Trends Biotechnol 1997; 15: 178-85. 